\title{
Labelling and Content Evaluation of Commercial Veterinary Probiotics
}

\author{
J. LATA 1, J. JURÁNKOVÁ ${ }^{2}$, J. DOUBEK ${ }^{3}$, V. PŘÍBRAMSKÁ ${ }^{1}$, P. FRIČ ${ }^{4}$, P. DÍTĚ ${ }^{1}$, M. KOLÁ $\check{R}^{5}$, \\ P. SCHEER ${ }^{3}$, D. KOSÁKOVÁ ${ }^{3}$ \\ ${ }^{1}$ Department of Internal Medicine and Gastroenterology, University Hospital, Brno \\ ${ }^{2}$ Department of Microbiology, University Hospital, Brno \\ ${ }^{3}$ Department of Physiology, Veterinary and Pharmaceutical University Brno \\ ${ }^{4}$ Department of Internal Medicine, Central Military Hospital, Prague \\ ${ }^{5}$ Institute of Microbiology, University Hospital, Olomouc
}

Received August 23, 2005

Accepted December 12, 2005

\begin{abstract}
Lata J., J. Juránková, J. Doubek, V. Příbramská, P. Frič, P. Dítě, M. Kolář, P. Scheer, D. Kosáková: Labelling and Content Evaluation of Commercial Veterinary Probiotics. Acta Vet. Brno 2006, 75: 139-144.

The aim of our study was to evaluate the contents and labelling of five commercial probiotics marketed for veterinary administration. The information on the product was obtained from the inserted leaflet or the data on the package. Quantitative bacteriological culture was performed in all products, and isolates were identified via biochemical characteristics. Comparison of actual contents versus label claims was performed. Four products correctly provided information on expiry dates, species and quantity of bacteria per gram or kilogram of product. In one product, there was no probiotic species mentioned in the Czech text on the package. Culture examinations of all the three products containing Enterococcus faecium resulted in finding the declared quantity of bacteria. They also contained Lactobacillus sp. not mentioned in the leaflet. Culturing the mixture of Bacillus subtilis and Lactobacillus paracasei, we found only Bacillus subtilis in a quantity by one order lower than declared. In an incorrectly labelled product, Lactobacillus sp. was found instead of yeast species. Most commercial veterinary probiotic preparations are not accurately represented by label claims.
\end{abstract}

Probiotics, bacteriological examination, contents, preparation, bacteria

Probiotics, products used in the treatment of many diseases for centuries, were introduced into the therapeutic range of western medicine more than a hundred years ago. Over the last decade, they have become popular both in human and veterinary medicine and have attracted an enormous commercial interest. Considerably growing interest in probiotics may be expected in veterinary medicine both for therapeutic reasons and growth promotion. Antibiotics still used for this indication are to be banned throughout the European Union completely in 2006 due to increasing resistance not only in animals but also in humans. Probiotics as safe products without any side effects are much more favourable. In human medicine it was confirmed that positive effects particularly concerned diseases of the gastrointestinal tract (Frič 2001; Fooks and Gibson 2002) as well as many other disorders, e.g. of the immune system (Coppola and Gil-Turnes 2004), hepatic diseases (Liu et al. 2004), and others. In veterinary medicine, probiotics have been used since 1980's (Underdahl 1982) both therapeutically and as feed additives (Montes and Pugh 1993; Kumprecht and Zobač 1998; Herzig et al. 2003). Despite the growing number of studies, many professionals are still distrustful of probiotics. Scepticism starts with doubts about the contents of individual preparations and quantity of bacteria claimed by the producers. Many studies found lower numbers, none, or even completely different bacterial strains than claimed by producers of both human medicines (Maajama et al. 1995; Holzapfel et al. 2001) and veterinary preparations (We se 2002). 
In light of the above-mentioned facts, we decided to evaluate five probiotic products commonly used by veterinarians with respect to their qualitative and quantitative microbiological characteristics.

\section{Materials and Methods}

A total of five probiotic products commonly used in veterinary practice were evaluated in May 2005 after a week of recommended storage. They were examined using bacteriological culture. The evaluated probiotic products were assigned numbers 1 to 5 .

The sum of information on the product was obtained from the inserted leaflet or the data on the package. The components of probiotics claimed to include the yeast Saccharomyces cerevisiae with vitamins and mineral substances in one case, Enterococcus faecium with vitamins in three cases, and a combination of Bacillus subtilis and Lactobacillus paracasei in one product (Table 1). One gram of paste or powder containing the declared probiotic substance was dissolved in $10 \mathrm{ml}$ of broth and homogenized properly. The broth was then dissolved to yield ten-fold dilutions, and each dilution was cultured using a calibrated inoculating loop $(1 \mu \mathrm{l})$ on blood agars and VL agars for anaerobes and Sabouraud agar, selective medium for yeast. Culture media were kept at $37^{\circ} \mathrm{C}$ for 48 hours under aerobic as well as anaerobic conditions. Growing colonies were then identified according to their growth, morphology, microscopic findings and essential biochemical characteristics (Murray 1999).

Table 1. Declared data on the products

\begin{tabular}{|c|c|c|c|c|}
\hline Product & Contents & Quantity & Date of expiry & Dosage \\
\hline 1 & Enterococcus faecium NCIMB 11181 & $\begin{array}{l}1.8 \times 10^{12} \\
\mathrm{CFU} / \mathrm{kg}\end{array}$ & $2 / 8 / 2005$ & $\begin{array}{l}\text { 1-2 doses of paste daily per a piglet, } \\
2-4 \text { doses of paste daily per a calf }\end{array}$ \\
\hline 2 & Enterococcus faecium NCIMB 11181 & $\begin{array}{c}1 \times 10^{12} \\
\mathrm{CFU} / \mathrm{kg}\end{array}$ & $10 / 2005$ & $1 \mathrm{~g} / 10 \mathrm{~kg}$ of body weight of a dog \\
\hline 3 & $\begin{array}{l}\text { Bacillus subtilis } \\
\text { Lactobacillus paracasei }\end{array}$ & $\begin{array}{l}1 \times 10^{9} \mathrm{CFU} / \mathrm{g} \\
1 \times 10^{9} \mathrm{CFU} / \mathrm{g}\end{array}$ & $9 / 2005$ & for poultry and exotic birds \\
\hline 4 & $\begin{array}{l}\text { Enterococcus faecium } \\
+ \text { vit } \mathrm{A}, \mathrm{D}_{3}, \mathrm{E}, \mathrm{B}_{1}, \mathrm{~B}_{2}, \mathrm{~B}_{12} \text {, } \\
\mathrm{C} \text {, niacin, biotin }\end{array}$ & $2 \times 10^{9} \mathrm{CFU} / \mathrm{g}$ & $8 / 4 / 2006$ & $\begin{array}{l}0.5-1.0 \mathrm{ml} \text { of paste daily per } \\
\text { a dog, cat; } \\
0.25 \mathrm{ml} \text { of paste daily per a puppy, } \\
\text { kitten }\end{array}$ \\
\hline 5 & $\begin{array}{l}\text { Without a mention in the Czech } \\
\text { text label pasted over the box, both } \\
\text { the information leaflet and the original } \\
\text { text on the box stated an incorrect } \\
\text { name Saccharomyces cerevisiae } \\
\text { + dried yeasts, digestive enzymes, } \\
\text { B vitamins, mineral substances }\end{array}$ & not mentioned & $11 / 2007$ & $1 \mathrm{tbl}$ per $10 \mathrm{~kg}$ of body weight \\
\hline
\end{tabular}

\section{Results}

Four products correctly provided information on expiry dates, species and quantity of bacteria per gram or kilogram of the product. Quantities of each species were also given in products containing mixtures. In one product, there was no probiotic species mentioned in the text on the package. Uncovering the Czech text label pasted over the original package revealed English text mentioning a yeast species (incorrectly as Saccharomyces cerevisiae instead of the correct Saccharomyces cerevisiae), but providing no information on its quantity. The vial contained only Czech text and no data on the species and quantity of the probiotic. None of the evaluated products included data on the expected loss in quantity of micro-organisms during storage or their quantity on the date of expiry.

Culture examinations of all the three products containing Enterococcus faecium resulted in finding the declared quantity of bacteria. They contained, however, Lactobacillus sp. not mentioned in the leaflet. Culturing the mixture of Bacillus subtilis and Lactobacillus paracasei, we found only Bacillus subtilis in a quantity by one order lower than declared. 
As for the incorrectly labelled product, no yeasts grew on the culture, and again, Lactobacillus sp. was found (Table 2).

Table 2. Contents and the quantity of bacteria in the products studied

\begin{tabular}{|c|c|c|}
\hline Product & Contents & Quantity \\
\hline 1 & $\begin{array}{r}\text { Enterococcus faecium } \\
\text { Lactobacillus } \mathrm{sp} .\end{array}$ & $1.6 \times 10^{12}-1.3 \times 10^{13} / \mathrm{kg}$ \\
\hline 2 & $\begin{array}{r}\text { Enterococcus faecium } \\
\text { Lactobacillus } \mathrm{sp} .\end{array}$ & $7 \times 10^{12}-7 \times 10^{14} / \mathrm{kg}$ \\
\hline 3 & Bacillus subtilis & $1.8 \times 10^{6}-8 \times 10^{8} / \mathrm{g}$ \\
\hline 4 & $\begin{array}{r}\text { Enterococcus faecium } \\
\text { Lactobacillus } \mathrm{sp} .\end{array}$ & $3 \times 10^{9}-2 \times 10^{10} / \mathrm{g}$ \\
\hline 5 & Lactobacillus $\mathrm{sp}$. & \\
\hline
\end{tabular}

\section{Discussion}

Modern history of probiotics started in the last century with the author Metchnikoff (1908). German authors, however, consider the first description of a probiotic product to be that by Döderlein (1892) who suggested 16 years before Metchnikoff the use of vaginal bacteria producing lactic acid for purposes of inhibiting growth of pathogenic bacteria. Metchnikoff believed that the higher average age in some ethnic groups was due to their high intake of fermented milk products, and recommended their use.

Probiotics were originally defined as "micro-organisms promoting the growth of other micro-organisms," later as "live micro-organisms causing or promoting useful equilibrium of the autochthonous microbial populations of the gastrointestinal tract." These microorganisms are not necessarily a permanent component of the gastrointestinal tract, but should be "in favour of the general state of health" (Lilly 1965; Fuller 1989). Nowadays, probiotics are defined as "mono- or mixed cultures of live micro-organisms which, when administered, have positive effects on the host due to the improvement of its micro-flora" (Havenaar 1992).

Over the last decade we have been witnessing a growing interest in such therapy. There is, however, still some distrust due to the lack of extensive randomised studies. Evaluation according to the requirements of evidence-based medicine is difficult because there are many probiotic products with a wide range of efficacy, and the number of diseases in which probiotics may have positive effects is large, so there are many combinations possible. In veterinary medicine, the situation is much more complicated. Apart from the possible combinations of a probiotic product versus disease, there is a third factor, i.e. the target group of animals. For example, Lactobacillus rhamnosus commonly used in human medicine is able to survive in the dog. But colonisation is more difficult and the therapeutic effect is not quite clear (Weese and Anderson 2002). In the horse, the situation is even more complicated (Weese et al. 2003).

The surgeons' distrust is rationally rooted in their fear of not knowing exactly what they are administering. Another problem is that in many countries (e.g. in the USA), probiotics are ranged among food additives, not medicines. This results in considerably lower requirements for the quality of commercial probiotics. Scepticism starts already with a product not properly labelled. In an evaluation of the information on leaflets of a total of 44 commercially available human and veterinary probiotics, complete data, such as the species and its quantity, were found only in two human and nine veterinary products. None of these products, like the ones examined by us, included data on the quantity of microorganisms or on the date of expiry (We es e 2003). In our evaluation of probiotic products, 
sufficient data were provided in four of five products. In the fifth one, the information in Czech text was quite insufficient, lacking the content of the probiotics. Removing the Czech text label revealed a misspelled as well as insufficient text without information on quantity.

More serious flaws, however, concern the contents and quantity of bacteria contained both in veterinary and human products. Food additives in particular, claiming the presence of live and active cultures, may include different contents. There may be differences in the quantity of bacteria. One yoghurt tested contained even no live bacteria (Holzapfel et al. 2001). In some products by the same producer there are differences in the contents of bacteria. Maj a a ma et al. (1995) administered in their study a product which was supposed to contain Lactobacillus acidophilus in the quantity of $1 \times 10^{9}$ but actually, it contained Lactobacillus casei in the quantity of $4.4 \times 10^{7}$. Moreover, advertisements of some producers are misleading. For example, a company marketing a new probiotic product containing several bacterial strains cited many studies confirming the efficacy of the product. None of those studies, however, included their product (Karpa 2003). From this point of view, the situation in the Czech Republic is more favourable. In a study of 13 human probiotics, all were found to contain the species as well as quantity declared by the producers (Příbramská et al. 2005).

The situation in veterinary medicine is probably much worse. A Canadian study of eight veterinary and five human probiotics found that only three of the eight veterinary products were provided with data on the contents; most of the products contained a lower quantity than declared; five products lacked one or more of the strains declared; and three products contained strains differing from those declared to be present (We ese 2002).

In theory, the situation in Europe should be better. Regarding the possible complications in veterinary medicine, probiotics as feed additives have been under strict control by the European Union since 1993. Moreover, since 2000 every microbial strain used as a feed additive has to be approved by the European Union Commission (Becquet 2003). In our study on the products, the right species as well as correct quantities were cultured from three products only, namely all the products containing Enterococcus faecium. In 2004, Enterococcus faecium (NCIMB 11181) was approved by the European Union Commission to be used as a feed additive without a time limit (Commission regulation /EC/ No 1333/2004). In April 2005, the safety of the product containing Enterococcus faecium NCIMB 11181 was confirmed, and it was stated that the MIC values (the minimum inhibitory concentration) are below or equal to the SCAN break points, i.e. not resistant to antibiotics used both in human and veterinary practice (EFSA Journal 2005). The bacteria Enterococcus faecium is quite frequently used in veterinary probiotics. This bacterial species was contained in 12 probiotic products out of the total of 44 examined ones (Weese 2003), and in three of the five examined in our study. A frequent use of this species, however, is questionable because there is a well-founded fear of its possible pathogenic abilities as well as a high degree of antimicrobial resistance. Since 2001 it has been known that Enterococcus faecium may be the recipient of the gene encoding resistance to vancomycin (Lund and Edlund 2001). It is, however, true that all the products that were supposed to contain Enterococcus faecium only, were positive for the Lactobacillus sp. culture. This negative fact probably does not influence the therapeutic effect (Lactobacillus sp. is commonly used as a probiotic), but it influences the evaluation of the efficacy of individual probiotic products.

The fourth product lacked one declared strain, and another strain was cultured in a lower quantity than stated by the producer. The yeast species of the fifth product was missing completely; conversely, Lactobacillus sp. not mentioned by the producer grew on the culture. Such cases of total lacks, lower quantities or even undeclared micro-organisms may influence the therapeutic effect of the product. It is, therefore, advisable to be stricter in 
checking the quality of marketed probiotics and it is absolutely necessary to perform microbiological examinations of the products used for clinical studies.

\section{Obsah bakterií ve veterinárních probioticích}

Cílem studie bylo zhodnotit kvalitu označení a obsah pěti veterinárních probiotik. Informace o preparátech byly získány z př́ibalového letáku, při jeho absenci z obalu léku. U všech preparátů bylo provedeno kvantitativní bakteriologické vyšetření a isoláty byly identifikovány biochemickými charakteristikami. Bylo provedeno porovnání skutečného obsahu s obsahem inzerovaným. Čtyři produkty obsahovaly řádnou informaci o expiraci, druhu a množství bakterií. U jednoho léku nebyl v českém textu uveden rod bakterie. Mikrobiologické vyšetření všech tří preparátů, které obsahovaly Enterococcus faecium, potvrdilo deklarované množství bakterií. Obsahovaly však navíc i Lactobacillus sp., který nebyl v informačním letáku uveden. Při kultivaci preparátu, který měl obsahovat Bacillus subtilis a Lactobacillus paracasei byl nalezen pouze Bacillus subtilis v množství o jeden řád nižším, nežli bylo deklarováno. V nedostatečně označeném přípravku byl namísto kvasinek nalezen rod Lactobacillus sp. U většiny komerčních veterinárních preparátů není soulad mezi označením a skutečným obsahem. $\mathrm{V}$ jednom př́ípadě může tento nedostatek ovlivnit terapeutické působení léku.

\section{Acknowledgements}

The study was supported by the Internal Grant Agency of the Ministry of Health of the Czech Republic (NK 7366-3).

\section{References}

ANONYMOUS 2004: Commission regulation (EC) No 1333/2004. 2004, Official Journal of the European Union 21.7.2004 L247/11-12

ANONYMOUS 2005: Opinion of the scientific panel on additives and products or substances used in animal feed on a request from the commission on the safety of the product Lactiferm for chickens for fattening for use as a feed additive. The EFSA J 207: 1-6

BECQUET P. 2003: EU assessment of enterococci as feed additives. Int J Food Microbiol 88: 247-254

COPPOLA MM, GIL-TURNES C, 2004: Probiotics and immune response. Cienc Rural 34: 1297-1303

DÖDERLEIN A 1892: Das Scheidensekret und seine Bedeutung für das Puerperalfieber. (The vaginal transsudate and its significance for childbed fever.) Zentralblatt für Bacteriologie 11: 699-700

FOOKS LJ, GIBSON GR 2002: Probiotics as modulators of the gut flora. Brit J Nutr 88: S39-S49

FRIČ P 2001: Probiotika v gastroenterologii. Aktuální přehled. Ces Slov Gastroenterol Hepatol 55: 237-241

FULLER R 1989: Probiotics in man and animals. J Appl Bacteriol 66:365-378

HAVENAAR R, TEN BRINK B, HUIS VELD JHJ 1992. Selection of strains for probiotic use. In: Fuller R, ed. Probiotics: the scientific basis. London: Chapman and Hall: 209-224

HERZIG I, GÖPFERT, E, PÍSAŘÍKOVÁ, B, STRAKOVÁ E. 2003: Testing of growth promoting and protective activity of the probiotic lactiferm in weaned piglets. Acta Vet Brno 72: 331-338

HOLZAPFEL WH, HABERER P, GEISEN R BJORKROTH J, SCHILLINGER U 2001: Taxonomy and important features of probiotic microorganisms in food and nutrition. Am J Clin Nutr 73: 365S-373S

KARPA KD 2003: Selecting probiotics. 237-261 In: Karpa KD: Bacteria for Breakfast, Trafford Publishing, Canada

KUMPRECHT I, ZOBAČ P 1998: The effect of probiotic preparations containing Saccharomyces cerevisiae and Enterobacter faecium M-74 and mannan-oligosaccharides in diets for weanling piglets. Czech J Anim Sci 43: 477-481

LILLY DM, STILLWELL RH 1965: Probiotics: growth promoting factors produced by microorganisms. Science 147: 747-748

LIU Q, DUAN ZP, HA DK., BENGMARK S, KURTOVIC J, RIORDAN SM 2004: Symbiotic modulation of gut flora: effect on minimal hepatic encephalopathy in patients with cirrhosis. Hepatology 39: 1441-1449

LUND B, EDLUND CH 2001: Probiotic Enterococcus faecium strain is a possible recipient of the vanA gene cluster. Clin Inf Dis 32: 1384-1385

MAJAAMA H, ISOLAURI E, SAXELIN M 1995: Lactic acid bacteria in the treatment of acute rotavirus gastroenteritis. J Ped Gastroenterol Nutr 20: 333-333

METCHNIKOFF E 1908: Prolongation of life. New York: Putnam 
MONTES AJ, PUGH DG 1993: The use of probiotics in food-animal practice. Vet Med 88: 282-288

MURRAY P, BARON E, PFALLER M 1999: Manual of clinical microbiology. American Society for Microbiology, Washington, DC.

PŘÍBRAMSKÁ V, JURÂNKOVÁ J, LATA J, ŠENKYŘÍK M, KROUPA R 2005: Evaluation of labeling and content of probiotics available in the Czech Republic. Vnitř Lék 51: in press

UNDERDAHL NR 1982: Effect of Streptococcus faecium C-68 in control of Escherichia coli-induced diarrhoea in gnotobiotic pigs. Am J Vet Res 43: 2227-2232

WEESE JS 2002: Microbiologic evaluation of commercial probiotics. J Am Vet Med Assoc 220: 794-797

WEESE JS 2003: Evaluation of deficiencies in labelling of commercial probiotics. Can Vet J. 44: 982-983

WEESE JS, ANDERSON MEC 2002: Preliminary evaluation of Lactobacillus rhamnosus strain GG, a potential probiotic in dogs. Can Vet J 43: 771-774

WEESE JS, ANDERSON MEC, LOWE A, MONTEITH GJ 2003: Preliminary investigation of the probiotic potential of Lactobacillus rhamnosus strain GG in horses: faecal recovery following oral administration and safety. Can Vet J 44: 299-302 